Doi: 10.47650/pjphsr.v1i2.253

ISSN (Online): 2777-1296

OJS: http://journal.unpacti.ac.id/index.php/pjphsr

\title{
DETERMINANTS OF NUTRITIONAL STATUS OF WAHDAH ISLAMIYAH INTEGRATED ISLAMIC ELEMENTARY SCHOOL STUDENTS 01 MAKASSAR CITY
}

\section{Determinan Status Gizi Murid Sekolah Dasar Islam Terpadu Wahdah Islamiyah 01 Kota Makassar}

\author{
Albara Indra ${ }^{1 *}$, Andi Maryam², Risma Haris ${ }^{2}$ \\ ${ }^{1}$ Mahasiswa Program Studi IImu Kesehatan Masyarakat, Program Pascasarjana Universitas Indonesia Timur, Makassar \\ ${ }^{2}$ Program Pascasarjana Universitas Indonesia Timur, Makassar
}

*Alamat Korespondensi: indraalbarra@gmail.com

\begin{tabular}{l}
\hline Article Info \\
\hline Article History \\
Received: 24 Juli 2021 \\
Revised : 28 Juli 2021 \\
Accepted : 29 Juli 2021
\end{tabular}

\section{Keywords :}

Nutritional status, head of family incomes, diet, snacking habits, counseling officers.

\footnotetext{
Kata kunci :

Status Gizi,

Pendapatan Kepala

Keluarga, Pola

Makan, kebiasaan

Jajan, Penyuluhan

Petugas.
}

\begin{abstract}
ABSTRAK
The increasing prevalence of abnormal nutritional status, especially malnutrition, overweight and obesity in childhood. This study aims to assess the determinants associated with the Nutritional Status of Elementary School Students. This type of research is an analytical survey with a cross sectional study approach. This research was carried out at SDIT Wahdah Islamiyah 01 Makassar City which was carried out in MayJune 2021. The population and sample were all students from grade one to grade six as many as 182 students using the total sample technique. Data obtained by direct interviews with respondents using a questionnaire. Data analysis with chi-square. The results showed that the income of the head of the family $(p=0.005)$, eating patterns $(p=$ 0.031), snack habits ( $p=0.026)$, counseling officers ( $p(0.030)$ were related to the Nutritional Status of Students. Of the four variables, the variables most related to the nutritional status of students is the income variable of the head of the family with an expected value of 6.367. The conclusion is that the factors related to the nutritional status of elementary school students are the income of the head of the family, eating patterns, snack habits, health counseling, and the income of the head of the family are the most related factors. Nutritional status for families and elementary school students to be able to regulate and maintain a diet with the principle of a balanced menu and always update information related to nutrition.
\end{abstract}

Meningkatnya prevalensi status gizi tidak normal terutama kekurangan gizi, kelebihan berat badan dan obesitas pada masa kanak-kanak. Penelitian ini bertujuan untuk menilai faktor determinan yang berhubungan dengan Status Gizi Murid Sekolah Dasar. Jenis penelitian survey analitik dengan pendekatan cross sectional study, Penelitian ini dilaksanakan di SDIT Wahdah Islamiyah 01 Kota Makassar yang dilaksanakan pada bulan Mei-Juni 2021. Populasi dan sampel adalah seluruh murid kelas satu sampai kelas enam sebanyak 182 siswa dengan menggunakan teknik total sampel. Data yang diperoleh dengan wawancara langsung terhadap responden dengan menggunakan kuesioner. Analisis data dengan chi-square. Hasil diperoleh bahwa pendapatan kepala keluarga $(p=0,005)$, pola makan $(p=0,031)$, kebiasaan jajan $(p=0,026)$, penyuluhan petugas ( $p$ $(0,030)$ berhubungan dengan Status Gizi Murid. Dari keempat variabel tersebut variabel yang paling berhubungan dengan status gizi murid adalah variabel pendapatan kepala keluarga dengan nilai expected $=6.367$. Kesimpulan di peroleh bahwa faktor yang berhubungan dengan status gizi murid sekolah dasar adalah pendapatan kepala keluarga, pola makan, kebiasaan jajan, penyuluhan kesehatan, serta pendapatan kepala keluarga merupakan faktor yang paling berhubungan dengan status Gizi. Bagi keluarga dan murid sekolah dasar agar dapat mengatur dan menjaga pola makan dengan prinsip menu seimbang dan selalu mengupdate informasi terkait gizi. 


\section{PENDAHULUAN}

Anak usia sekolah merupakan salah satu kelompok yang rawan mengalami gizi kurang terutama pada masa pertumbuhan dan perkembangannya sering mengalami masalah gizi. Masalah gizi terutama gizi kurang dapat menghambat pertumbuhan dan perkembangan anak usia sekolah. Gizi yang optimal sangat diperlukan pada anak usia sekolah, karena dampaknya secara langsung berkaitan dengan pencapaian sumber daya manusia yang berkualitas. Gizi yang optimal sangat diperlukan pada anak usia sekolah karena dampaknya secara langsung berkaitan dengan pencapaian sumber daya manusia yang berkualitas (Maitland, Malcolm and Handfield, 2015). Gizi yang berkualitas sangat penting karena pada usia tersebut anak mengalami tumbuh kembang yang pesat (Sugiyanto, Sumarlan and Hadi, 2020). Selain itu anak usia sekolah dapat dijadikan media pembawa perubahan (agent ofchange) bagi pembentukan perilaku gizi bagi diri sendiri dan keluarganya (Słowik et al., 2019).

Meningkatnya prevalensi status gizi tidak normal terutama, kekurangan gizi, kelebihan berat badan dan obesitas pada masa kanak-kanak, tercermin dari data tren cross-sectional, telah banyak dilaporkan secara global tetapi terutama di negara-negara berkembang. Hal ini semakin diakui sebagai masalah kesehatan masyarakat yang serius di negara yang terakhir, yang mencakup negara-negara Karibia seperti Kepulauan Turks dan Caicos (Maitland et al., 2014).

Secara global, sekitar $10 \%$ anak usia sekolah 5-19 tahun dinilai kelebihan berat badan atau obesitas. Tingkat prevalensi berkisar dari sekitar 6\% di Pakistan (Jafar et al., 2018) hingga 42\% di Meksiko (Moraes et al., 2006). Peningkatan global dalam prevalensi kelebihan berat badan dan obesitas pada orang muda juga diamati di Karibia (Schwiebbe et al., 2011). Beberapa penelitian telah menunjukkan hubungan status gizi seperti kekurangan gizi, kelebihan berat badan pada anak-anak dan perkembangan penyakit tidak menular kronis (PTM), termasuk hipertensi, diabetes tipe 2 dan penyakit kardiovaskular (CVD) bahkan sampai dewasa. Kenaikan berat badan juga telah dikaitkan dengan berbagai faktor risiko CVD seperti hiperlipidemia dan toleransi glukosa abnormal (Han, Lawlor and Kimm, 2010). Oleh karena itu, ada kebutuhan mendesak untuk mengevaluasi status gizi dan inisiatif yang dirancang untuk mendorong gaya hidup sehat pada anak sekolah dasar dan memanfaatkan data untuk menginformasikan pengembangan kebijakan dan untuk campur tangan yang diperlukan untuk menghentikan atau membalikkan tren kelebihan berat badan/obesitas yang meningkat (Gaskin et al., 2012).

Berdasarkan Riskesdas (2010), secara nasional prevalensi status gizi pada anak usia 6-12 tahun terdiri dari, 4,6\% sangat kurus, 7,6\% kurus, $78,6 \%$ normal dan $19,2 \%$ gemuk. Sedangkan prevalensi status gizi anak usia 6-12 di Jawa Tengah terdiri dari 5,3\% sangat kurus, $8 \%$ kurus, $75,8 \%$ normal dan 10,9\% gemuk (Litbangkes, 2010). Berdasarkan Kemenkes bahwa Indonesia diperoleh data pada tahun 2016 gizi buruk terbanyak ditemukan diwilayah NTT (Nusa tenggara timur) dengan persentase $6,9 \%$ dari kasus, selanjutnya Kalimantan barat dengan kasus $6,7 \%$ dan pada urutan ke tiga adalah Maluku dengan kasus $6 \%$. Sementara Sulawesi selatan berada pada posisi ke enam dengan jumlah persentase 5\%. Hal ini menunjukkan kasus gizi buruk di Sulawesi Selatan masih berada di atas rata-rata nasional yang berada di angka 3,4 persen.

Hasil Riskesdas 2018 menunjukkan bahwa Nusa tenggara Timur masih menduduki posisi teratas meskipun mengalami penurunan kasus dari 33 ribu kasus pada tahun 2013 menjadi 295 ribu kasus (RI, 2018). Berdasarkan data Dinas Kesehatan Provinsi Sulawesi Selatan tahun 2017 menunjukkan bahwa 800.00 murid Sekolah Dasar di Sulawesi Selatan mengalami gizi buruk dan 272.000 murid kurang gizi (Sulsel, 2018). Data Dinkes Kota Makassar tahun 2019 menunjukkan 
bahwa murid usia 6-12 tahun dengan prevalensi gizi kurang sebanyak $15,6 \%$ pada murid laki-laki dan sebanyak $16,9 \%$ pada perempuan (Makassar, 2019).

Status gizi yang baik akan menghasilkan SDM yang berkualitas yaitu sehat, cerdas dan memiliki fisik yang tangguh serta produktif. Status gizi buruk akan berdampak jangka panjang pada intelektual anak dan kelak kemudian hari akan menderita penyakit degemeratif. Perbaikan gizi diperlukan pada seluruh siklus kehidupan, mulai sejak dini. Masukan gizi anak sangat tergantung pada sumber-sumber yang ada di lingkungan sosialnya, salah satu yang menentukan adalah ibu. Pendapatan keluarga dan peranan orang tua, khususnya ibu, dalam menyediakan dan menyajikan makanan bergizi bagi keluarga, khususnya anak menjadi penting. Kualitas pelayanan ibu dalam keluarga ditentukan oleh penguasaan informasi dan faktor ketersediaan waktu yang memadai. Kedua faktor tersebut antara lain faktor determinan yang dapat ditentukan dengan tingkat Pendidikan pendapatan, pelayanan kesehatan, kebiasaan jajan, interaksi sosial dan pekerjaan. Penelitian ini bertujuan untuk menganalisis determinan status gizi Murid Sekolah Dasar Islam Terpadu Wahdah Islamiyah 01 Kota Makassar.

\section{BAHAN DAN METODE}

Jenis penelitian yang digunakan dalam penelitian ini adalah Survey Analitik dengan pendekatan cross sectional study, yaitu untuk mengetahui hubungan variabel dependen dengan variabel independen yang diamati pada periode waktu yang sama. Penelitian ini akan dilaksanakan di Sekolah Dasar Islam Terpadu Wahdah Islamiyah 01 Kota Makassar pada bulan Mei-Juni Tahun 2021. Populasi dan sampel adalah seluruh murid kelas satu sampai kelas enam Sekolah Dasar Islam Terpadu Wahdah Islamiyah 01 Kota Makassar tahun 2021 sebanyak 182 siswa dengan menggunakan teknik pengambilan sampel secara total sampel (exhaustic sampling) serta pengumpulan data dengan pengukuran Berat
Badan (BB) dan menggunakan kuesioner penelitian. Analisa datadigunakan uji chi-square dengan tingkat keamanan $\alpha=0,05$.

\section{HASIL}

Penelitian ini dilaksanakan di Sekolah Dasar Islam Terpadu Wahdah Islamiyah 01 Kota Makassar selama 1.080 hari mulai pada tanggal 23 Juli 2019 sampai dengan 10 Juni 2021, dengan mengambil sampel sebanyak 182 murid sekolah dasar. Data diolah dan dianalisis disesuaikan dengan tujuan penelitian. Hasil analisis data disajikan dalam bentuk tabel yang dilengkapi dengan penjelasan sebagai berikut.

Tabel 1. Distribusi Karakteristik Murid Sekolah Dasar Islam Terpadu Wahdah Islamiyah 01 Kota Makassar

\begin{tabular}{|ll}
\hline \multicolumn{1}{c}{ Karakteristik Murid } & $\mathbf{n}(\%)$ \\
\hline $\begin{array}{c}\text { Jenis Kelamin } \\
\text { Laki-laki }\end{array}$ & \\
\hline $\begin{array}{c}\text { Perempuan } \\
\text { Kelompok Umur (tahun) }\end{array}$ & $85(46,3)$ \\
\hline $5-7$ & \\
\hline $8-10$ & $59(32,4)$ \\
\hline $11-13$ & $96(52,7)$ \\
\hline Kelas Murid & $27(14,8)$ \\
\hline Kelas 1 & \\
\hline Kelas 2 & $17(9,3)$ \\
\hline Kelas 3 & $48(26,4)$ \\
\hline Kelas 4 & $49(26,9)$ \\
\hline Kelas 5 & $30(16,5)$ \\
\hline Kelas 6 & $22(12,1)$ \\
\hline IMT/U (Kg) & $16(8,8)$ \\
\hline $9-10$ & \\
\hline $11-12$ & $4(2,2)$ \\
\hline $13-14$ & $16(8,8)$ \\
\hline $15-16$ & $63(34,6)$ \\
\hline $17-18$ & $58(31,9)$ \\
\hline $19-20$ & $14(7,7)$ \\
\hline $21-22$ & $10(5,5)$ \\
\hline $23-24$ & $8(4,4)$ \\
$\geq 25$ & $4(2,2)$ \\
\hline
\end{tabular}

Tabel 1 menunjukkan bahwa dari 182 murid terdapat yang memiliki jenis kelamin laki-laki sebanyak $53,3 \%$, dan perempuan sebanyak $46,7 \%$, 
tertinggi yang memiliki kelompok umur $8-10$ tahun sebanyak $52,7 \%$, dan terendah kelompok umur $11-13$ tahun sebanyak $14,8 \%$, tertinggi yang menyatakan kelas 2 dan 3 masing-masing sebanyak 26,9\%, dan terendah kelas 6 sebanyak $8,8 \%$, tertinggi yang memiliki indeks massa tubuh per umur 13 - $14 \mathrm{~kg}$ sebanyak 34,6\%, dan terendah indeks massa tubuh per umur $9-10 \mathrm{~kg}$ dan 23-24 kg masing - masing sebanyak 2,2\%.

Tabel 2 dibawah menunjukkan bahwa dari 63 kepala keluarga murid yang menyatakan pendapatan keluarga < Rp. 2.941.270.00, terdapat memiliki status gizi tidak normal sebanyak $58,7 \%$. Sedangkan dari 119 keluarga murid yang menyatakan pendapatan keluarga > Rp. 2.941.270.00, terdapat yang memiliki status gizi tidak normal sebanyak $37,0 \%$. Dengan nilai $p$ $(0,005)<0,05$. Ini berarti pendapatan kepala keluarga berhubungan dengan status gizi murid. Dari 43 murid yang menyatakan pola makan kurang, terdapat yang memiliki status gizi tidak normal sebanyak 30,2\%. Sedangkan dari 139 murid yang menyatakan pola makan cukup, terdapat yang memiliki status gizi tidak normal sebanyak $48,9 \%$ dengan nilai $p(0,031)<0,05$. Ini berarti pola makan berhubungan dengan status gizi murid, dari 51 murid yang memiliki kebiasaan jajan terdapat yang memiliki status gizi tidak normal sebanyak 31,4\%. Sedangkan dari 131 murid yang menyatakan tidak memiliki kebiasaan jajan, terdapat yang memiliki status gizi tidak normal sebanyak $49,6 \%$ dengan nilai $p(0,026)<$ 0,05 . Ini berarti kebiasaan jajan berhubungan dengan status gizi murid serta dari 61 murid yang menyatakan penyuluhan petugas kurang terdapat yang memiliki status gizi tidak normal sebanyak $55,7 \%$. Sedangkan dari 121 murid yang menyatakan penyuluhan petugas cukup, terdapat yang memiliki status gizi tidak normal sebanyak $38,8 \%$ dengan nilai $p(0,030)<0,05$. Ini berarti penyuluhan petugas berhubungan dengan Status Gizi Murid.

Tabel 2. Hubungan Variabel Determinan dengan Status Gizi Murid di Sekolah Dasar Islam Terpadu Wahdah Islamiyah 01 Kota Makassar

\begin{tabular}{|c|c|c|c|c|c|c|}
\hline \multirow{3}{*}{ Variabel Determinan } & \multicolumn{4}{|c|}{ Status Gizi } & \multirow{3}{*}{ Jumlah } & \multirow{3}{*}{$\begin{array}{l}X^{2} \\
(p)\end{array}$} \\
\hline & \multicolumn{2}{|c|}{ Tidak Normal } & \multicolumn{2}{|c|}{ Normal } & & \\
\hline & $\mathrm{n}$ & $\%$ & $\mathbf{n}$ & $\%$ & & \\
\hline \multicolumn{6}{|l|}{ Pendapatan Kepala Keluarga } & \multirow{3}{*}{$\begin{array}{c}7,894 \\
(0,005)\end{array}$} \\
\hline$<$ Rp.2.941.270.00 & 37 & 58,7 & 26 & 41,3 & 63 & \\
\hline >Rp.2.941.270.00 & 44 & 37,0 & 75 & 63,0 & 119 & \\
\hline \multicolumn{6}{|l|}{ Pola Makan } & \multirow{3}{*}{$\begin{array}{c}4,644 \\
(0,031)\end{array}$} \\
\hline Kurang & 13 & 30,2 & 30 & 69,8 & 43 & \\
\hline Cukup & 68 & 48,9 & 71 & 51,1 & 139 & \\
\hline \multicolumn{6}{|l|}{ Kebiasaan Jajan } & \multirow{3}{*}{$\begin{array}{c}4,948 \\
(0,026)\end{array}$} \\
\hline Jajan & 16 & 31,4 & 35 & 68,6 & 51 & \\
\hline Tidak Jajan & 65 & 49,6 & 66 & 50,4 & 131 & \\
\hline \multicolumn{6}{|l|}{ Penyuluhan Petugas } & \multirow{3}{*}{$\begin{array}{c}4,687 \\
(0,030)\end{array}$} \\
\hline Kurang & 34 & 55,7 & 27 & 44,3 & 61 & \\
\hline Cukup & 47 & 38,8 & 74 & 61,2 & 121 & \\
\hline
\end{tabular}

Tabel 3 menunjukkan bahwa pendapatan kepala keluarga $(p=0,000)$, pola makan $(p=$ $0,001)$, kebiasaan jajan $(p=0,131)$, penyuluhan petugas $(p=0,003)$ berhubungan dengan status gizi murid. Dari keempat variabel tersebut variabel yang paling berhubungan dengan status gizi murid adalah variabel pendapatan kepala keluarga dengan nilai expected $=6.36$. 
Tabel 3. Analisis Multivariat Status Gizi Murid di Sekolah Dasar Islam Terpadu Wahdah Islamiyah 01 Kota Makassar

\begin{tabular}{lcccccc}
\hline \multicolumn{1}{c}{ Variabel } & \multirow{2}{*}{ B } & Sig & Exp (B) & Wald & \multicolumn{2}{c}{ 95\% C for EXP (B) } \\
\cline { 6 - 8 } & & & & & Lower & Upper \\
\hline Pendapatan Kepala Keluarga & 1.851 & 0.000 & 6.367 & 13.672 & 2.367 & 16.985 \\
\hline Pola Makan & -2.398 & 0.001 & 0.091 & 11.414 & 0,023 & 0.365 \\
\hline Kebiasaan Jajan & $-0,791$ & 0,131 & 0.453 & 2.275 & 0.162 & 1.267 \\
\hline Penyuluhan Petugas & 1.454 & 0,003 & 4.280 & 8.979 & 1.654 & 11.078 \\
\hline \multicolumn{1}{c}{ Constant } & 0.335 & 0.675 & 1.398 & 0.176 & & \\
\hline
\end{tabular}

\section{PEMBAHASAN}

\section{Pendapatan Kepala Keluarga Dengan Status Gizi Murid}

Status gizi murid merupakan suatu hal yang menentukan tingkat kesejahteraan masyarakat dan kualitas sumber daya manusia. Kemiskinan menjadi salah satu penyebab tertinggi terjadinya gizi kurang, dengan kondisi pendapatan yang rendah menyebabkan keluarga tidak mampu memenuhi kebutuhan gizi yang berdampak pada pemenuhan gizi pada murid. Menurut asumsi peneliti, keluarga dengan pendapatan tidak terpenuhi tetapi memiliki anak dengan gizi normal yaitu sebanyak 26 murid (41.3\%), hal ini terjadi karena, keluarga bisa memamfaatkan perkarangan rumah untuk menanam bahan makanan yang mengandung nilai gizi untuk anaknya, memvariasikan macam-macam masakan yang bergizi dari bahan makanan yang dimamfaatkan di perkarangan rumah, suaminya sering menangkap ikan di sungai untuk dikonsumsi sendiri, sehingga murid gizi anak dapat terpenuhi. Sedangkan responden dengan pendapatan keluarga yang terpenuhi namun memiliki anak dengan gizi tidak normal sebanyak 37 murid $(58,7 \%)$, hal ini dapat disebabkan keluarga dalam hal ini ibu tidak bisa mengelola keuangan dengan baik meskipun pendapatan terpenuhi, namun tidak membelajakan uang sesuai dengan kebutuhan gizi. Tingkat pendapatan merupakan faktor yang menentukan kualitas dan kuantitas makanan yan dikonsumsi. Kemampuan keluarga untuk membeli bahan makanan tergantung pada besar kecilnya pendapatan, keluarga dengan pendapatan terbatas kemungkinan besar akan kurang dapat memenuhi kebutuhan makananya terutama untuk memenuhi kebutuhan zat gizi dalam tubuh.

Umumnya jika pendapatan naik, jumlah dan jenis makanan cenderung ikut bervariasi. Tingkat penghasilan ikut menentukan jenis pangan apa yang akan dibeli dengan adanya tambahan uang. Semakin tinggi penghasilan, semakin besar pula persentase dari penghasilan tersebut dipergunakan untuk membeli buah, sayur mayur dan berbagai jenis bahan pangan lainnya. jadi penghasilan merupakan factor penting bagi kualitas dan kuantitas antara penghasilan dan gizi jelas ada hubungan yang menguntungkan. Pengaruh peningkatan penghasilan terhadap perbaikan kesehatan dan kondisi keluarga lain yang mengadakan interaksi dengan status gizi yang berlawanan hampir universal. Hal ini dikarenakan karena rendahnya kemampuan untuk memenuhi gizi yang baik. Selain itu, seorang ibu rumah tangga yang sehari-harinya terbiasa menyiapkan makanan bagi anggota keluarganya harus mempunyai pengetahuan dan ketrampilan tentang menu sehat dan gizi seimbang, sehingga makanan yang disajikan menarik untuk dikonsumsikan dan balita tidak bosan.

Keterampilan ibu sangat diperlukan dalam upaya peningkatan status gizi anaknya secara baik, dalam mengatur makanan agar menjadi lebih berguna bagi tubuh, secara umum dinegara berkembang ibu memegang peranan penting 
dalam memilih dan mempersiapkan pangan untuk dikonsumsi keluarga. Pendapatan yang rendah dapat mempengaruhi banyak hal seperti pola konsumsi makanan kurang bergizi, pemeliharaan kesehatan dan sebagainya. Salah satu akibat kurangnya kesempatan kerja adalah rendahnya pendapatan masyarakat. Salah satu yang menyebabkan pendapatan keluarga menjadi rendah adalah tingkat pendidikan yang terlampau rendah.

Hasil penelitian ini sejalan dengan penelitian Andriani E.P (2012) di Sekolah Dasar 02 Ngesrep Banyumanik, Semarang menyatakan bahwa pendapatan keluarga $(p=0,0001)$ berhubungan dengan status gizi pada siswa sekolah dasar(Pahlevi, 2012). Status gizi murid sangat dipengaruhi rendahnya pendapatan merupakan rintangan yang menyebabkan orang-orang tidak mampu membeli pangan dalam jumlah yang diperlukan (Migunova and Sadykov, 2018). Rendahnya pendapatan itu mungkin disebabkan menganggur atau setengah menganggur karena susahnya memperoleh lapangan kerja tetap sesuai yang diinginkan, keluarga dengan pendapatan terbatas mempunyai kemungkinan kurang dapat memenuhi kebutuhan makanan sejumlah yang diperlukan, setidaknya keanekaragaman bahan makanan kurang dapat dijamin, karena dengan uang terbatas itu tidak akan banyak pilihan.

Hubungan Pola Makan Dengan Status Gizi Murid Pola makan merupakan berbagai informasi yang memberikan gambaran mengenai macam dan jumlah gahan makanan yang dimakan satu hari oleh satu orang atau merupakan ciri khas untuk satu kelompok masyarakat tertentu sedangkan pengertian pola makan adalah semua makanan yang sering dipersiapkan untuk dikonsumsi yang dapat diketahui dengan cara perhitungan skor dari makanan yang dikonsumsi. Makanan merupakan sesuatu yang esensial bagi kehidupan manusia. Manusia membutuhkan makanan untuk bisa beraktifitas sehari-hari. Oleh karena itu pentingnya makanan yang sangat besar. Manusia memiliki pola makan yang berbeda untuk dapat beraktifitas sehari-hari. Hal ini dikarenakan murid yang tinggal bersama orang tua mendapatkan perhatian khusus mengenai makanannya. Ibu memegang peranan penting dalam menyediakan makanan yang bergizi bagi keluarga, sehingga memiliki pengaruh terhadap status gizi anak. Pola makan dalam penelitian ini yang memiliki hubungan yang signifikan secara statistik dengan status gizi murid. Variabel ini berhubungan signifikan secara negatif saat diuji secara independen tanpa mengontrol faktor lain, sehingga ketika murid kelas satu sampai enam melakukan pengontrolan berat badan maka akan menurunkan status gizinya. Pola makan merupakan cara makan baik di rumah maupun di luar rumah, yang meliputi frekuensi dan waktu makan, jenis dan jumlah makanan yang dikonsumsi, termasuk makanan yang disukai dan makanan pantangan. Pertumbuhan pada usia anak juga dipengaruhi oleh asupan zat gizi yang dikonsumsi dalam bentuk makanan. Kekurangan atau kelebihan zat gizi akan menyebabkan pertumbuhan yang menyimpang. Gangguan gizi pada usia anak sering terjadi, seperti KEK dan anemia, serta defisiensi berbagai vitamin. Sebaliknya, masalah gizi lebih (overweight) yang ditandai oleh tingginya obesitas anak terjadi terutama di kota-kota besar (Sayogo, 2011).

Hasil penelitian ini menunjukkan bahwa laki-laki di sekolah dasar memiliki asupan daging, karbohidrat, dan lemak yang lebih tinggi, tetapi asupan buah, dan sayuran secara signifikan lebih tinggi pada siswa sekolah dasar perempuan. Memang, asupan karbohidrat dan protein harian sudah tepat, sementara porsi lemak cukup tinggi, sesuai dengan penelitian sebelumnya(Peykari et al., 2011). Namun, konsumsi beberapa zat gizi makro pada remaja tidak memenuhi rekomendasi standar. Faktanya, kelompok roti dan sereal memenuhi rekomendasi standar AKG, sedangkan lemak dan minyak, asupan gula lebih tinggi dari jumlah harian yang direkomendasikan. Baik pria maupun wanita memiliki konsumsi buah yang rendah, meskipun konsumsinya jauh lebih rendah pada pria. Secara umum, penelitian ini dan 
penelitian serupa menunjukkan bahwa peserta laki-laki memiliki konsumsi sayuran dan buahbuahan yang jauh lebih rendah dan asupan karbohidrat, lemak, dan daging yang lebih tinggi dibandingkan dengan rekan perempuan mereka (Lir and Perevalov, 2019).

Hasil analisis statistik hubungan pola makan dengan status gizi murid menunjukkan hubungan yang signifikan $(p<0,001)$. Penelitian ini sejalan dengan penelitian sebelumnya yang menjelaskan ada hubungan antara pola makan dan status gizi murid $(p=0,040)$. Hasil tersebut menjelaskan bahwa anak dengan pola makan kurang berisiko 3 kali lebih tinggi untuk menjadi status gizi tidak normal. Sementara pada penelitian di Amerika Latin menjelaskan bahwa hubungan antara kekurangan gizi dan yang tidak kurang gizi mengalami perubahan yang cepat pada pola makan dan kegiatan fisik pada anak sekolah (Duran, Caballero and De Onis, 2016).

Pada penelitian di Mesir menjelaskan bahwa kondisi sosial ekonomi berpengaruh pada pola asupan makan atau gizi anak, selain itu faktor genetik harus diperhatikan. Keadaan status gizi pada anak usia sekolah disebabkan oleh pola asupan makan yang kurang seperti protein, dan lemak yang dapat menyebabkan tingginya prevalensi status gizi tidak normal sebanyak 22,1\% (Assis et al., 2014).

\section{Hubungan Kebiasaan Jajan Dengan Status Gizi Murid}

Praktek kebiasaan jajan menjadi perhatian dalam bidang gizi. Sementara anak-anak yang sangat kecil membutuhkan makanan kecil dan padat gizi serta camilan, peningkatan jumlah kesempatan makan telah dikaitkan dengan peningkatan asupan energi pada anak-anak, baik di AS dan Meksiko (Evans et al., 2015). Kebiasaan diet yang terbentuk di masa kanak-kanak dapat memengaruhi perilaku asupan makanan di kemudian hari, hasil berat badan dan kesehatan jangka panjang (Mozaffarian et al., 2011). Oleh karena itu, penting bagi pengasuh anak untuk membantu mereka mengembangkan perilaku diet sehat sejak dini (Jacquier, Deming and Eldridge,
2018). Penelitian ini menemukan bahwa pola makan anak-anak rendah buah-buahan dan sayuran dan bahwa sekitar $85 \%$ anak-anak sekolah muda mengonsumsi beberapa jenis makanan jajan manis seperti makanan penutup, permen, minuman manis atau camilan asin pada hari tertentu (Pabayo et al., 2012).

Jajan juga dapat dipengaruhi oleh sosial budaya, budaya makanan, dan status sosial ekonomi (Bellisle, 2014). Meskipun pembahasan secara komprehensif tentang sejumlah besar faktor lingkungan yang memengaruhi makan berada di luar cakupan ulasan ini, beberapa faktor yang relevan dengan ngemil, termasuk model sosial dan kerawanan pangan. Beberapa penelitian telah menunjukkan bahwa jumlah makanan yang dikonsumsi oleh teman mempengaruhi ukuran porsi makan, efek yang disebut sebagai "model sosial". Menurut tinjauan baru-baru ini, efek ini terutama telah dipelajari dalam konteks konsumsi makanan ringan. Jika teman makan mengonsumsi makanan dalam porsi besar, orang yang makan bersamanya juga cenderung makan lebih banyak (Hadi, Ishak and Rantesalu, 2021). Kebalikannya benar dengan makanan dalam jumlah kecil. Bahkan jika pendamping makan tidak ada, isyarat lingkungan tentang asupan dan pilihan makanan individu sebelumnya, seperti pembungkus makanan kosong, dapat mempengaruhi asupan (Prinsen, de Ridder and de Vet, 2013). Peningkatan pengaruh teman makan selama waktu camilan mungkin karena kurangnya "rutinitas makan" atau "bahan" untuk ngemil sebagai acara makan, sedangkan makan cenderung lebih dibatasi oleh perilaku atau tempat tertentu (Hermans et al., 2010).

Konsumsi makanan ringan juga dapat dimulai karena acara-acara sosial perayaan serta ketersediaan atau keinginan untuk makanan yang menggoda. Inventarisasi ini secara khusus dikembangkan untuk menilai alasan individu mengonsumsi camilan tidak sehat yang mengandung banyak lemak atau gula dan menemukan bahwa alasan paling umum mengonsumsi camilan tidak sehat termasuk 
merayakan pesta atau acara khusus atau mengidam makanan lezat. Studi lain meminta 55 orang dewasa untuk membuat buku harian diet selama 5 hari dan menilai alasan mereka untuk makan dengan menggunakan skala yang sama dengan hanya 13 item (Cleobury and Tapper, 2014).

Dalam penelitian ini, alasan paling umum untuk mengonsumsi jajanan tidak sehat adalah karena "terlihat atau berbau begitu menggoda" (55\% dari kesempatan ngemil), diikuti oleh "lapar" (49\%) dan "membutuhkan energi" (23\%). Jajan tergantung pada faktor eksternal antara lain seperti waktu, jenis makanan, ketersediaan makanan, dan lokasi. Namun, dampak dari seringnya makan pada hasil kesehatan, termasuk penambahan berat badan, sebagian besar masih belum diketahui. Literatur menunjukkan bahwa konsumsi makanan ringan yang miskin nutrisi dapat dikaitkan dengan BMI tinggi, makan tanpa rasa lapar, makan jauh dari rumah atau tempat kerja, model sosial, dan kerawanan pangan. Meskipun faktor-faktor ini mungkin terkait dengan pilihan makanan yang buruk di beberapa populasi, motivasi untuk ngemil serta dampak kesehatan dari ngemil tunduk pada variasi antarindividu yang cukup besar, yang memerlukan penyelidikan lebih lanjut. Karena makanan yang sangat asin, manis, dan tinggi lemak seperti keripik, makanan penutup, dan minuman berpemanis gula masih menjadi camilan paling populer di beberapa negara, pedoman diet dapat mengubah "makanan ringan" untuk mencegah "waktu camilan" menjadi kesempatan untuk makan berlebihan makanan miskin atau rendah gizi.

\section{Hubungan Penyuluhan Petugas Dengan Status Gizi Murid}

Penting untuk mengembangkan kebiasaan makan yang baik selama masa kanak-kanak dan remaja karena kebiasaan makan mempengaruhi pertumbuhan dan sulit diubah. Penyuluhan kesehatan terutama pendidikan gizi dan pola makan memajukan pengetahuan gizi dan perilaku diet anak-anak secara positif mempengaruhi asupan gizi mereka secara keseluruhan (Hadi et al., 2021), sedangkan konseling gizi meningkatkan gaya hidup diet melalui manajemen gizi disesuaikan yang mempertimbangkan status gizi individu, gangguan, dan status kesehatan (Kim et al., 2015).

Penelitian ini mengkaji tugas guru gizi dan ahli gizi di SD dalam tiga kategori penyelenggaraan food service, pendidikan gizi dan pola makan, dan penyuluhan gizi. Melalui langkah-langkah tersebut, penelitian ini bertujuan untuk mengidentifikasi metodologi pendidikan diet dan konseling gizi yang komprehensif dan praktis. Petugas kesehatan terutama Guru gizi umumnya ditemukan lebih tua dari ahli gizi, dan dengan pengalaman kerja lebih lama, meskipun ahli gizi memiliki tingkat pendidikan yang lebih tinggi. Han juga menyatakan bahwa guru gizi umumnya lebih tua dari ahli gizi. Dilihat dari jenis pendirian sekolah, petugas kesehatan terutama guru gizi umumnya bekerja di sekolah nasional dan negeri, sedangkan ahli gizi bekerja di sekolah nasional, negeri, dan swasta. Dalam penyelenggaraan foodservice, guru gizi umumnya memasak sendirisendiri dengan pengelolaan dan memasak bersama, sedangkan ahli gizi hanya memasak sendiri-sendiri (Han, 2015).

Selain itu, sebuah penelitian menunjukkan bahwa ada lebih dari dua kali jumlah ahli gizi dengan gelar lebih tinggi dari Master dibandingkan dengan guru gizi, yang sejalan dengan temuan penelitian ini. Masalahnya adalah bahwa ahli gizi tanpa gelar pendidikan telah pergi ke sekolah pascasarjana, yang mensertifikasi mereka sebagai guru gizi; namun, ada sangat sedikit karyawan baru untuk guru gizi. Hasil tersebut menunjukkan bahwa guru gizi sekolah dan ahli gizi menganggap pengaturan rencana pendidikan gizi, pelaksanaan pendidikan gizi, dan konseling gizi penting tetapi sulit; kesulitan yang terkait dengan pendidikan dan konseling gizi karena rendahnya tingkat pengetahuan dan kepercayaan diri dan rendahnya persepsi manajemen sekolah sejalan dengan penelitian lain (Bae et al., 2015). Oleh karena itu, harus ada 
dukungan kelembagaan dan pendidikan bagi ahli gizi sekolah untuk menjadi ahli dalam pendidikan dan konseling gizi terutama tenaga kesehatan.

Meskipun ada dasar hukum untuk menempatkan petugas kesehatan sebagai guru gizi di sekolah, ada dukungan kelembagaan yang lemah untuk membantu guru gizi ini melaksanakan tugasnya di sekolah. Mereka biasanya tidak dapat terlibat dalam peran asli mereka dalam memberikan pendidikan gizi, dan lebih fokus pada operasi jasa makanan yang ada. Menurut penelitian yang ada tentang pendidikan gizi, lebih dari 95\% kepala sekolah, orang tua, dan guru menunjukkan bahwa pendidikan gizi diperlukan, dan lebih dari $85 \%$ percaya bahwa pendidikan gizi harus disampaikan oleh guru gizi (Park et al., 2016). Namun, meskipun kebutuhan akan pendidikan gizi sangat tinggi, tingkat pelaksanaan yang sebenarnya masih rendah. Sementara sekolah dasar melihat pelaksanaan pendidikan gizi lebih aktif dibandingkan dengan sekolah menengah dan tinggi, penyampaian langsung pendidikan gizi. You dkk. mengidentifikasi persepsi dan tingkat kebutuhan pada item yang memerlukan suplemen yang berkaitan dengan tugas dan institusi untuk guru gizi (You, Lee and Park, 2016). Namun, karena banyaknya pekerjaan yang diharapkan dari guru gizi dan ahli gizi, beban operasi kelas, dan kurangnya kurikulum pendidikan mandiri, pendidikan kehidupan diet yang ditawarkan di sekolah menghadapi berbagai kendala. Berdasarkan hasil penelitian ini, kami memberikan rekomendasi untuk mencapai gizi praktis dan komprehensif dan pendidikan gizi hidup dan konseling gizi, yang kinerjanya ditemukan jauh lebih rendah daripada operasi jasa makanan. Pelayanan petugas kesehatan terutama tenaga gizi dan ahli gizi menghadapi kesulitan dalam menawarkan pendidikan dan konseling gizi karena pekerjaan yang berlebihan yang berkaitan dengan makanan sekolah dan tugas administrasi, sehingga kurangnya waktu untuk pendidikan dan konseling. Oleh karena itu, harus ada metode untuk mengurangi pekerjaan administrasi yang tidak perlu sehingga pendidikan dan penyuluhan gizi dan pola makan dapat dilaksanakan secara efektif. Selain itu, harus diberikan waktu kelas independen, akhirnya menetap sebagai kelas reguler dengan sendirinya. Pengembangan berbagai materi pendidikan tentang nutrisi dan pola makan juga penting untuk memastikan bahwa kelas memenuhi berbagai kebutuhan pendidikan dan tingkat keterampilan siswa.

\section{KESIMPULAN DAN SARAN}

Penelitian ini diperoleh kesimpulan bahwa ada hubungan pendapatan kepala keluarga, pola makan, kebiasaan jajan, penyuluhan kesehatan dengan status gizi serta Faktor yang paling berhubungan dengan Status Gizi Murid Sekolah Dasar Islam Terpadu adalah pendapatan kepala keluarga. Bagi keluarga agar dapat mengatur pola makan anaknya terutama mengosumsi makanan yang mengandung zat gizi lengkap serta lebih aktif mengikuti pendidikan gizi berupa penyuluhan gizi terkait status gizi dan makanan seimbang.

\section{DAFTAR PUSTAKA}

Assis, A. M. de O. et al. (2014) 'Childhood stunting in Northeast Brazil: the role of Schistosoma mansoni infection and inadequate dietary intake', European Journal of Clinical Nutrition. Nature Publishing Group, 58(7), pp. 1022-1029.

Bae, I.-S. et al. (2015) 'Perception of the elementary school dietitians and students on nutrition education to set up the roles of nutrition teacher-Centered on Daegu city and Gyeongbuk province', Journal of the Korean Dietetic Association. The Korea Dietetic Association, 11(4), pp. 393-404.

Bellisle, F. (2014) 'Meals and snacking, diet quality and energy balance', Physiology \& behavior. Elsevier, 134, pp. 38-43.

Cleobury, L. and Tapper, K. (2014) 'Reasons for eating 'unhealthy'snacks in overweight and obese males and females', Journal of Human Nutrition and Dietetics. Wiley Online Library, 27(4), pp. 333-341. 
Duran, P., Caballero, B. and De Onis, M. (2016) 'The association between stunting and overweight in Latin American and Caribbean preschool children', Food and nutrition bulletin. SAGE Publications Sage CA: Los Angeles, CA, 27(4), pp. 300-305.

Evans, E. W. et al. (2015) 'The role of eating frequency on total energy intake and diet quality in a low-income, racially diverse sample of schoolchildren', Public health nutrition. Cambridge University Press, 18(3), pp. 474-481.

Gaskin, P. S. et al. (2012) 'Diet, physical activity, weight status, and culture in a sample of children from the developing world', Journal of nutrition and metabolism. Hindawi, 2012.

Hadi, A. J. et al. (2021) 'Effect of Dissemination of Resources and Information Method for Overnutrition Prevention Behavior on Primary School Children in Makassar', Medico Legal Update, 21(2), pp. 189-195.

Hadi, A. J., Ishak, S. and Rantesalu, M. (2021) 'The rule of nutrition counseling media to students' snacking behavior', Jurnal Gizi dan Dietetik Indonesia (Indonesian Journal of Nutrition and Dietetics), 8(2), pp. 54-60.

Han, J.-I. (2015) 'The work performance and the factor contributing to the work performance of nutrition teacher \& school dieticians', Journal of Nutrition and Health. The Korean Nutrition Society, 48(6), pp. 558-570.

Han, J. C., Lawlor, D. A. and Kimm, S. Y. S. (2010) 'Childhood obesity', The lancet. Elsevier, 375(9727), pp. 1737-1748.

Hermans, R. C. J. et al. (2010) 'Social modeling effects on snack intake among young men. The role of hunger', Appetite. Elsevier, 54(2), pp. 378-383.

Jacquier, E. F., Deming, D. M. and Eldridge, A. L. (2018) 'Location influences snacking behavior of US infants, toddlers and preschool children', BMC public health. BioMed Central, 18(1), pp. 1-10.

Jafar, T. H. et al. (2018) 'Rise in childhood obesity with persistently high rates of undernutrition among urban school-aged
Indo-Asian children', Archives of disease in childhood. BMJ Publishing Group Ltd, 93(5), pp. 373-378.

Kim, J. S. et al. (2015) 'Effects of school-based nutrition education for Korean food guide on food intake frequency of adolescents', Korean Journal of Community Nutrition. Korean Society of Community Nutrition, 10(5), pp. 582-591.

Lir, D. N. and Perevalov, A. Y. (2019) 'Analysis of actual home nutrition of urban children of pre-school and school age', Voprosy pitaniia, 88(3), pp. 69-77.

Litbangkes, B. (2010) 'Riset kesehatan dasar (Riskesdas) 2010', Badan Litbangkes, Kementerian Kesehatan. Jakarta.

Maitland, T. E. et al. (2014) 'Trends in obesity and other cardiovascular disease risk factors among elementary school children in the Turks and Caicos Islands (2008-2013)', West Indian Med J, 63(Suppl 2), p. 48.

Maitland, T. E., Malcolm, S. and Handfield, S. (2015) 'Nutritional knowledge and practices, lifestyle characteristics and anthropometric status of Turks and Caicos Islands elementary school children', The West Indian Medical Journal. The University of the West Indies, 64(1), p. 29.

Makassar, D. K. (2019) 'Profil kesehatan kota Makassar tahun 2019', Makassar: Dinas Kesehatan Kota Makassar.

Migunova, Y. V and Sadykov, R. M. (2018) 'Nutrition of children in modern Russian family: social and economic aspect', Voprosy pitaniia, 87(2), pp. 103-107.

Moraes, S. A. de et al. (2006) 'Prevalence of overweight and obesity, and associated factors in school children from urban area in Chilpancingo, Guerrero, Mexico, 2004', Cadernos de Saúde Pública. Scielo Brasil, 22(6), pp. 1289-1301.

Mozaffarian, D. et al. (2011) 'Changes in diet and lifestyle and long-term weight gain in women and men', New England Journal of Medicine. Mass Medical Soc, 364(25), pp. 2392-2404.

Pabayo, R. et al. (2012) 'Food consumption 
patterns: In preschool children', Canadian Journal of Dietetic Practice and Research. Dietitians of Canada, 73(2), pp. 66-71.

Pahlevi, A. E. (2012) 'Determinan status gizi pada siswa sekolah dasar', Jurnal Kesehatan Masyarakat, 7(2), pp. 122-126.

Park, Y.-H. et al. (2016) 'A survey on practice of nutrition education and perception for implementing nutrition education by nutrition teacher in elementary schools', Journal of Nutrition and Health. The Korean Nutrition Society, 39(4), pp. 403-416.

Peykari, N. et al. (2011) 'A peer-based study on adolescence nutritional health: A lesson learned from Iran', JPMA-Journal of the Pakistan Medical Association, 61(6), p. 549.

Prinsen, S., de Ridder, D. T. D. and de Vet, E. (2013) 'Eating by example. Effects of environmental cues on dietary decisions', Appetite. Elsevier, 70, pp. 1-5.

RI, K. (2018) 'Hasil Utama Riset Kesehatan Dasar Tahun 2018', Kementrian Kesehat Republik Indones, pp. 1-100.

Sayogo, S. (2011) 'Asupan Energi dan Zat Gizi Kurang Dari Angka Kecukupan Gizi Remaja
Putri'. Jakarta: FK UI.

Schwiebbe, L. et al. (2011) 'Childhood obesity in the Caribbean', West Indian medical journal. University of the West Indies, 60(4), pp. 442-445.

Słowik, J. et al. (2019) 'Nutritional Status Assessment in Children and Adolescents with Various Levels of Physical Activity in Aspect of Obesity', Obesity facts. Karger Publishers, 12(5), pp. 554-563.

Sugiyanto, S., Sumarlan, S. and Hadi, A. J. (2020) 'Analysis of Balanced Nutrition Program Implementation Against Stunting in Toddlers', Unnes Journal of Public Health, $9(2)$.

Sulsel, D. (2018) 'Profil Kesehatan Sulawesi Selatan Tahun 2018', Makassar: Dinas Kesehatan Provinsi Sulawesi Selatan.

You, J. E., Lee, Y. E. and Park, E. H. (2016) 'Actual status of task performance and need for system improvement for nutrition teachers', Journal of the Korean Society of Food Science and Nutrition. The Korean Society of Food Science and Nutrition, 45(3), pp. 420-436. 